\title{
Modelling potential spawning habitat of sardine (Sardina pilchardus) and anchovy (Engraulis encrasicolus) in the Bay of Biscay
}

\author{
Benjamin Planque ${ }^{1,{ }^{*}}$, Edwige Bellier $^{1}$ And Pascal Lazure ${ }^{2}$
}

1IFREMER, Département Ecologie et Modèles pour l'Halieutique, rue de l'île d'Yeu, BP21105, 44311 Nantes Cedex 3, France

2IFREMER, Laboratoire de Physique Hydrodynamique et Sédimentaire, BP 70, 29280 Plouzané, France.

* Correspondance. e-mail: benjamin.planque@ifremer.fr

\begin{abstract}
:
Large amplitude variations in recruitment of small pelagic fish result from interactions between a fluctuating environment and population dynamics processes such as spawning. The spatial extent and location of spawning, which is critical to the fate of eggs and larvae, can vary strongly from year to year, as a result of changing population structure and environmental conditions. Spawning habitat can be divided into 'potential spawning habitat', defined as habitat where the hydrographic conditions are suitable for spawning, 'realized spawning habitat', defined as habitat where spawning actually occurs, and 'successful spawning habitat', defined as habitat from where successful recruitment has resulted. Using biological data collected during the period 2000-2004, as well as hydrographic data, we investigate the role of environmental parameters in controlling the potential spawning habitat of anchovy and sardine in the Bay of Biscay. Anchovy potential spawning habitat appears to be primarily related to bottom temperature followed by surface temperature and mixed-layer depth, whilst surface and bottom salinity appear to play a lesser role. The possible influence of hydrographic factors on the spawning habitat of sardine seems less clear than for anchovy. Modelled relationships between anchovy and sardine spawning are used to predict potential spawning habitat from hydrodynamical simulations. The results show that the seasonal patterns in spawning are well reproduced by the model, indicating that hydrographic changes may explain a large fraction of spawning spatial dynamics. Such models may prove useful in the context of forecasting potential impacts of future environmental changes on sardine and anchovy reproductive strategy in the north-east Atlantic.
\end{abstract}

Keywords: Potential spawning habitat, sardine, anchovy, GAMs, environmental effects, Bay of Biscay 


\section{INTRODUCTION}

\section{Defining the Spawning habitats}

Although small pelagic fish spawning habitats have been the central focus of a large number of studies, a clear definition of spawning habitats is often lacking and different authors have used the same terminology for concepts that can radically differ in terms of ecological understanding. The most common, and often implicit definition of spawning habitat is "geographical location where eggs are found" (see e.g. Daskalov et al., 2003, Lynn, 2003) which can be directly derived from egg surveys. Another definition which is also often not explicitly stated is "set of environmental conditions that are suitable for spawning" (see e.g. Checkley et al., 2000, van der Lingen et al., 2001). The use of the term "spawning habitat" for these two definitions often depends on the state of advancement of the observation (field sampling) and understanding of the relationships between spawning adults and their environment. The terminology may also be used for the two definitions in the same publication. The related terminology "suitable spawning habitat" which often refers to the fate of eggs could be stated "region where the conditions are suitable for eggs and larvae survival" (see e.g. Bakun, 1996, Agostini and Bakun, 2002) and is related to the habitat suitability of Fretwell (1972): "the average potential contribution from that habitat to the gene pool of succeeding generations of the species". The set of hypotheses, the physical and biological processes involved as well

20 as the means of investigations necessary to study spawning habitat will vary greatly depending on the underlying definition of what is the "spawning habitat".

To clarify the nature of the spawning habitat studied, we have separated spawning habitat into three distinct components. Each habitat component has specific characteristics which may depend upon the abiotic and biotic environment, population structure and observation techniques. The methods available to study each habitat component may also be specific. A schematic representation of the three habitat components is given in Figure 1. This distinction between habitat components has been proposed during the GLOBEC-SPACC (Global Ocean Ecosystem Dynamics - Small Pelagics and Climate Change) workshop on spawning habitat and assessment of small pelagic fish (van der Lingen and Castro, 2004): 
1. Potential spawning habitat:

"Habitat where the environmental conditions are suitable for spawning". The potential spawning habitat may be seen as the largest envelope of spawning habitat. Based on environmental characteristics, it defines the set of conditions that a given species may find suitable for spawning. Spatial and seasonal extent of potential spawning habitat will be primarily affected by variability in climate and the environment. It can not be observed directly from individual regional field cruises which are more suited to study "realised spawning habitat" (see below). To define potential spawning habitat it is necessary to observe spawning in all possible suitable environmental conditions. In practice, defining potential spawning habitat requires that data collected over a wide range of environmental conditions are collated. These data have to include information on areas and seasons when spawning does not/never occur. Experimental results on the biological and physiological characteristics of a given species can also be used to define its potential spawning habitat. Potential spawning habitat can still be defined for areas where a population has collapsed and no spawning actually occurs. Potential spawning habitat has some similarities with the "basin" model of McCall (1990). However, the potential spawning habitat depends on spawning, but not on the contribution to population growth rate, i.e. subsequent recruitment, as is the case in McCall's basin model. Recruitment related issues will be considered in the "successful spawning habitat" below.

\section{Realised spawning habitat}

"Habitat where spawning actually occurs". The realised spawning habitat is defined by the region where fish actually spawn in a given year at a given time. It is bounded by the potential spawning habitat. Factors that affect the location and extent of realised spawning habitat are primarily related to adult population size and structure as well as density dependent processes. The extent to which fish will use the potential spawning habitat will depend upon the number of mature fish, their age, migration, mating behaviour, and other population traits, as well as possible interaction with other populations in the same areas (predators, competitors and preys). Density dependent habitat selection (DDHS, MacCall, 1990) will be primarily related to realised spawning habitat. The realised spawning habitat is the one generally observed during egg surveys. It is expected that realised spawning 
habitat will display larger year-to-year fluctuations than will potential spawning habitat. Note that comparing directly observed realised habitat with environmentally based potential habitat may in most cases not make sense, since there is no reason a priori that a given population will fully occupy the available potential habitat in a given year.

3. Successful spawning habitat

"Habitat where fish have spawned and from where successful recruitment has resulted". The successful spawning habitat is defined by the fate of eggs spawned into it. It is bounded by the realised spawning habitat (and consequently by the potential spawning habitat). Factors that affect realised spawning habitat are factors that will affect eggs, larvae and juveniles after spawning has taken place. The successful spawning habitat can not be observed at the time of spawning but only after young fish enter the population as recruits. It has to be inferred from information on juveniles and young adults. The successful spawning habitat can also be studied by numerical modelling (and in particular IBM models) by following cohorts or individuals and their environment during their early life stages.

The present study focuses on possible ways to define and model anchovy and sardine "potential spawning habitat" in the Bay of Biscay. The issues related to realised and successful habitat will be briefly discussed.

Anchovy and sardine spawning habitats in the Bay of Biscay

The study of anchovy and sardine populations in the Bay of Biscay goes back at least to the early $20^{\text {th }}$ century (Fage, 1911, Furnestin, 1945), but it is only in the early 1960s that systematic sampling of sardine and anchovy eggs and larvae over most of the Bay of Biscay continental shelf was undertaken (Arbault and Boutin, 1967). These surveys were carried out and used by Arbault and Lacroix $(1971,1977)$ to produce the first description of sardine and anchovy spawning in the area. The geographical occupation of sardine and anchovy extends beyond the Bay of Biscay, with sardine ranging from the western African coast (Furnestin and Furnestin, 1959, Ettahiri et al., 2003) to southern Norway (Parrish et al., 1989) and anchovy ranging from western Africa $\left(5^{\circ} \mathrm{N}\right)$

30 to the northern North Sea (Reid, 1966, Anonymous, 1985). However, the two populations appear in substantial quantities in the Bay of Biscay and both spawn in the area. The spatial and seasonal extent of spawning in the Bay of Biscay has been 
reviewed and re-analysed in Bellier et al. (submitted). They have shown that for the two species, spawning areas can be divided into recurrent (or refuge) sites where spawning is observed every year and optional sites where the probability of spawning varies greatly from year-to-year. In addition, it appears that the average spawning region has moved from the 1960-70s to the present period 2000-2004, possibly as a result of environmental changes.

\section{Anchovy}

Anchovy spawning occurs preferentially close to the coast and sometimes at the shelf break or in oceanic slope water eddies (Motos et al., 1996). Spawning season extends from March to August with a maximum intensity between May and June. Intensity of spawning appears to be constrained by thermal environment: Arbault and Lacroix (1977) have reported anchovy spawning within a thermal window of $14-20^{\circ} \mathrm{C}$, Sola et al. (1990) have found a thermal window of $16.5-19^{\circ} \mathrm{C}$ whilst according to Motos et al. (1996) the thermal range is between 14 and $18^{\circ} \mathrm{C}$. In other regions the thermal constraints may be slightly different, for example van der Lingen et al. (2001) reports thermal range of $17.4-21.1^{\circ} \mathrm{C}$ in the Benguela region. In his world-wide analysis of anchovy distribution, Reid (1966) argues that the genus Engraulis is found from estuaries to high salinity waters, so that it is associated with coastal areas rather than with water of a given salinity range. Whilst river plumes (i.e. low salinity) appear to be recurrent preferential areas for spawning, anchovy also spawns in other areas such as slope water eddies or shelf break which are characterised by high salinity throughout the water column. Although there is a converging set of evidence that increase in river runoff is associated to increase in anchovy recruitment (see Lloret et al., 2004 and references therein), the association between anchovy spawning and salinity is less obvious than for temperature and the influence of salinity on anchovy spawning distribution is still a matter of debate. Stratification, retention and plankton production have been proposed as other controlling factors for anchovy spawning (or spawning success) in the Bay of Biscay (Motos et al., 1996). However, there has yet been no quantitative assessment of the link between these factors and anchovy spawning.

Finally, spawning habitat appears to depend (1) on seasonal timing, with adults migrating north and west as season progress (Uriarte et al., 1996) and (2) on adult population size with spawning habitat extent increasing with adult population size 
(Motos et al., 1996). This latter effect is directly related to "realised", rather than "potential" spawning habitat.

\section{$\underline{\text { Sardine }}$}

In the Bay of Biscay, sardine spawning occurs within a thermal window of 12.5$15^{\circ} \mathrm{C}$ according to Sola et al. (1990) and of $10-16^{\circ} \mathrm{C}$ according to Arbault and Lacroix (1977). The spatial distribution of sardine is generally more widespread and fragmented than that of anchovy. Optimal temperature for spawning sardine can vary greatly between regions and between studies. In the North Pacific the thermal range for Sardinops sagax is often given as about $13.5-17^{\circ} \mathrm{C}$ (Tibby, 1937, Ahlstrom, 1965, Parrish et al., 1989, Lluch-Belda et al., 1991), although Hammann et al. (1998) report much warmer temperature range of $16.9-20.8^{\circ} \mathrm{C}$ and conversely Lynn (2003) report spawning occurring in colder temperature of $12-13^{\circ} \mathrm{C}$ off southern and central California. In the Benguela upwelling system, the range of temperature for spawning sardine (Sardinops sagax) is bimodal, with a major peak at $15.5-17.5^{\circ} \mathrm{C}$ and a secondary peak between 18.7 and $20.5^{\circ} \mathrm{C}$ (van der Lingen et al., 2001). In south Pacific waters, Ward and Staunton-Smith (2002) report spawning temperature range of $14-23^{\circ} \mathrm{C}$. Off the Moroccan coast (north west Africa) Sardina pilchardus spawning is observed within the temperature range 16$18.5^{\circ} \mathrm{C}$ (Furnestin and Furnestin, 1959, Ettahiri et al., 2003). The seasonality of spawning appears to vary with latitude as a result of latitudinal gradients in sea surface temperature regimes (Stratoudakis et al., 2004). The impact of salinity has been little described for sardine populations.

\section{Objectives of the study}

In the present study, we attempt to define the set of hydrographic conditions that are suitable for spawning of sardine and anchovy populations, i.e. to define the potential spawning habitat of sardine and anchovy in the Bay of Biscay. To do so, we aggregate data on fish egg and hydrology collected during five spring surveys (2000-2004) in the Bay of Biscay. The presence of eggs (modelled as a probability of presence as in Bellier et al., submitted) is then related to hydrographic conditions by generalised additive modelling. Our intention is to test whether our observations during the period 20002004 confirm previous conclusions on the possible influence of salinity and temperature on sardine and anchovy spawning habitat. In addition, we investigate the possible role 
of other hydrographic parameters related to water column stratification, on the potential spawning habitat of the two species. Finally, we show how this information can be used to represent potential spawning habitat on the basis of simulated hydrographic fields, as a first step towards predicting spawning habitat changes under possible climate 5 scenarios. 


\section{DATA AND METHOD}

\section{The PELGAS cruises 2000-2004}

Since 2000, large scale cruises covering most of the Bay of Biscay continental shelf along the French coast have been carried out during spring. These cruises are primarily

5 designed for the acoustic assessment of small pelagic fish stocks in the area. However, a number of additional data are collected, which include fish egg and larvae sampling, hydrology, phytoplankton and zooplankton sampling, sea mammals and sea bird observations. In the current study, we have used fish egg and hydrographic data.

Due to operational and logistical constraints, the cruises have taken place at different dates every year: $17^{\text {th }}$ April to $14^{\text {th }}$ May in $2000,28^{\text {th }}$ April to $4^{\text {th }}$ June in $2001,10^{\text {th }}$ May to $5^{\text {th }}$ June in $2002,30^{\text {th }}$ May to $24^{\text {th }}$ June in 2003 and $27^{\text {th }}$ April to $24^{\text {th }}$ May in 2004. As this is the period during which thermal stratification establishes and river runoff diminishes, slight changes in the timing of cruises can have a large impact on the hydrographic conditions encountered.

15 The cruise track showing the location of CUFES samples and Hydrographic stations in 2004 is shown in Figure 2. Cruise tracks for 2000, 2001, 2002 and 2003 are similar (although not strictly identical) to the one in 2004.

\section{Collection of egg samples - data processing}

Continuous fish egg sampling was performed using a CUFES (Continuous Underway 20 Fish Egg Sampler, Checkley et al., 1997), mounted outboard of the R/V Thalassa. The CUFES continuously pumps sea water at $3 \mathrm{~m}$ depth at a rate of about $500 \mathrm{1} / \mathrm{min}\left(8.3 .10^{-}\right.$ $\left.{ }^{3} \cdot \mathrm{m}^{3} \cdot \mathrm{s}^{-1}\right)$. The eggs are concentrated into a small volume of water and samples are collected every 20 minutes. A sample approximately corresponds to $10 \mathrm{~m}^{3}$ of filtered sea water whilst the ship has covered a distance of about 3 nautical miles $(5.5 \mathrm{~km})$. The exact pump flow rate and duration of sampling are recorded. After collection, the eggs are identified to species level for sardine and anchovy and are counted. The results are standardised to egg concentration i.e. "number of eggs per $10 \mathrm{~m}^{3}$ of filtered sea water". The distribution of egg presence in the Bay of Biscay derived from CUFES sampling is limited to the subsurface layer where water is pumped $(3 \mathrm{~m})$. However, the vertical distribution of fish eggs in the water column is rarely uniform or random (Coombs et al., 1985, Stenevik et al., 2001, Boyra et al., 2003) so that CUFES estimates may not 
truly reflect egg abundance in the water. To limit the discrepancies between true and observed egg abundance, the analysis was restricted to egg presence/absence as in most cases, when eggs were sampled with a vertical net (WP2, 200 microns mesh-size, bottom to surface haul), they were also found in CUFES samples. We envisaged the use of numerical models to simulate the vertical distribution of fish eggs in the water column. However, there are major difficulties is following such approach because (1) current models are designed to simulate egg abundance rather than egg presence, (2) different sets of models based on steady state solutions (Sundby, 1983, Boyra et al., 2003) or dynamic solutions (Westgard, 1989) do not provide identical results and (3)

10 recent results suggest that egg density may vary between years (Petitgas et al., 2004) but data on egg density of sardine and anchovy were not available for the period of study. As a consequence the modelling of egg vertical distribution was not undertaken and the results of this study only refer to subsurface egg presence/absence.

\section{Collection of hydrographic data - data processing}

15 Hydrographic profiles (temperature, salinity, density) were realised at fixed stations at night using a CTD probe. The number of stations realised has slightly varied between years. From each CTD profile, six parameters were derived: surface and bottom temperature, surface and bottom salinity, potential energy deficit and mixed layer depth. Potential energy deficit, which is a measure of vertical density stratification was

20 calculated as in Allain et al. (2001). Mixed layer depth was estimated using a two-layers model as in Planque et al. (2004). When vertical profiles exceeded $100 \mathrm{~m}$ depth, only the first 100 metres were retained for the analysis, as some external sensors mounted on the probe did not always allow for deeper sampling.

\section{Cartography of fish egg and hydrographic data}

25 Fish egg and hydrographic data were interpolated on the same spatial grid to allow direct comparison of the two types of data. The cartography of the probability of egg presence was performed as in Bellier et al. (submitted). Egg concentrations were transformed to presence/absence binary data, before being interpolated on a regular grid of $1 / 8^{\text {th }}$ degree by ordinary point kriging (Matheron, 1962, Cressie, 1993). The cartography of the six hydrographic parameters was also performed by kriging on the same regular grid of $1 / 8^{\text {th }}$ degree. Kriged data for fish eggs and hydrographic parameters were used as input to the Generalised Additive Model fitting. 


\section{$\underline{\text { Individual predictor fits }}$}

The definition of potential spawning habitat is based on the existence of a relationship between hydrographic factors and the probability of egg presence. Prior to modelling

5 potential spawning habitats, the kriged data (i.e. interpolated probabilities of egg presence and interpolated hydrographic predictors) from all years have been pooled in a single table. Generalised additive models (GAMs, Hastie and Tibshirani, 1990) constitute a practical method for fitting smoothed curves to sets of data with single or multiple predictor and single response variable. In a first step, we have used GAM

10 models with single predictors to identify the relationships between individual hydrographic predictors and the probability of egg presence. The selection of the GAMs smoothing predictors was done following the method proposed by Wood and Augustin (2002), using the 'mgcv' library in the R statistical software (R Development Core Team, 2004). The output of the GAMs are smoothed fits for each hydrographic predictors. The individual models can not be tested for significance using the $p$-values provided by 'mgcv' library since the true number of degrees of freedom is unknown, and probably much smaller than the one used to compute the $p$-value due to strong spatial autocorrelation in the data. However, each fit can be analysed with regards to the level of deviance explained (0-100\%, the highest, the better), the Generalised Cross

20 Validation score (GCV, the lowest the better) and the confidence region for the smooth (which should not include zero throughout the range of the predictor). The predictors can be ranked according the above criteria, so that the best model can be selected.

\section{$\underline{\text { Multiple predictor fits }}$}

GAMs allow for fitting a single response variable (here, the probability of egg presence) to multiple predictors (here, the hydrographic predictors). On the basis of predictor ranking performed above, we have constructed series of GAMs of increasing complexity to model the probability of egg presence for sardine and anchovy. The 'best' models for sardine and anchovy are again selected on the basis of GCV and level of deviance explained. These models form the basis of the potential habitat prediction (see below). 
Using the GAMs (constructed from observed egg distributions and hydrographic situations) it is possible to predict the probability of egg presence from a new set of hydrographic predictors. We have made such attempt using hydrographic results for 5 hydrodynamical simulations. The simulations are generated by a MARS3D, a 3D hydrodynamical model covering the Bay of Biscay continental shelf. The model has a $5 \mathrm{~km}$ horizontal resolution and 10 vertical layers in sigma coordinates. A detailed description of the model properties is given in Lazure and Jégou (1998) and Planque et al (2004). 


\section{RESULTS}

\section{Egg distribution}

The distribution of anchovy eggs is generally confined to the southern part of the Bay of Biscay continental shelf. There is a large degree of interannual variability in anchovy egg distribution. For example, the spatial distribution in 2003 is patchy and spreads over most of the shelf whilst in 2004 it is much narrower and concentrated along the southern coast of Les Landes and the Adour, Gironde and Loire estuaries (Fig. 3). Distribution of sardine eggs can extend throughout the area covered by the survey, i.e. the Bay of Biscay continental shelf. Eggs can be found at the southern and northern bounds and in coastal as well as shelf break areas. As in the case of anchovy, there is a high degree of interannual variability of the location and extent of sardine egg presence.

\section{Hydrology}

The distribution of sea surface temperature (SST, Fig. 4a) reflects the state of thermal stratification during the cruise. In 2000 and 2004 warmer temperatures were recorded in the northern part of the shelf as this area was visited at the end of the cruise, once stratification had taken place. In 2001, the sampling plan was reversed, with the southern part of the shelf visited during the second part of the cruise. This explains the apparent strong temperature gradient observed around 47N. In 2003 the cruise took place after the onset of thermal stratification and all SST display high values. Bottom temperatures display less interannual variability. The characteristic features are the presence of the "cold pool", a cold $\left(<12^{\circ} \mathrm{C}\right)$ bottom body of water (Vincent and Kurc, 1969, Puillat et al., 2004) visible in the northern part of the shelf in 2000, 2002 and 2004, and warm coastal water strips in 2001-2004 (Fig. 4b). The distribution of surface salinity (Fig. 4c) is related to the Loire and Gironde river outflows which have greatly varied during the five years. A maximum runoff in 2001 is visible with low salinity extending far out on the shelf and a low salinity water lens located in front of the Gironde estuary. Bottom salinity is not directly related to surface salinity and generally follows a the bathymetry towards the shelf break (Fig. 4d). The mixed layer depth (MLD, Fig. 4e) is also conditioned by local bathymetry with greater MLD in deeper waters. However, the geographical extent and location of maximum MLD along the shelf break vary between years, as seen for example in 2001 (maximum MLD around $47^{\circ} \mathrm{N}$ ) and in 2000 and 2004 (maximum MLD around $45^{\circ} \mathrm{N}$ ). The potential energy 
deficit (PED) reflects the combined thermal and haline stratification and is greatly variable between cruises (Fig. 4f). In 2000, the high PED in the north reflect thermal stratification towards the end of the cruise. In 2001 the northern stratified lens reflects thermal stratification in addition to the presence of low salinity water extending off the coast. The southern stratified lens is mostly the result of very low surface salinity in front of the Gironde estuary. In 2002, the averaged PED values reflect the average surface salinity and temperature distributions. In 2003 the late timing of the cruise combined with abnormally warm temperatures resulted in strong thermal stratification. Similarly, in 2004 the PED is parallel to the distribution of surface temperatures but 10 with much lower values.

In summary, the five cruises have taken place in contrasted hydrographic situations as a result of changes in individual cruise timing and meteorological conditions (e.g. high precipitation in 2001, strong solar heating in 2003). The six hydrographic parameters chosen provide complementary information and although they can be well structured in space (spatial autocorrelation) they are not strongly correlated with each other.

\section{Relationships between egg presence and individual hydrographic predictors}

\section{$\underline{\text { Temperature }}$}

The link between temperature and the spawning of anchovy is clearly visible (Fig. 5a,c left) with spawning mostly occurring in waters of $14.5-19^{\circ} \mathrm{C}$ at the surface and $12-15^{\circ} \mathrm{C}$ at the bottom. The upper temperature limits can not be clearly defined from the GAM plot as the coefficient does not decrease towards value significantly lower than zero. The lower bottom temperature limit is evident, with a sharp decline in coefficient values below $12^{\circ} \mathrm{C}$. The influence of temperature on the potential habitat of sardine is also visible (Fig 5a,c right). There appear to be a thermal preferendum around $12.5-15^{\circ} \mathrm{C}$ at the surface. For bottom temperature the response is bimodal with a first mode around $11.75^{\circ} \mathrm{C}$, and positive coefficients values beyond $12.5^{\circ} \mathrm{C}$.

\section{$\underline{\text { Salinity }}$}

Anchovy eggs are found preferentially in waters with low surface salinity ( $<34$ Fig. $5 d$ left) with almost a monotonic decline towards high salinity values. The influence of bottom salinity is less obvious although there is a decline in the GAM function with increasing salinity (Fig. 5b left). A small peak is observed for high salinity (around 
35.5) probably related to spawning observed in the region of the shelf break. For sardine the effect of surface salinity appears bimodal with ranges of $<33.5$ and $>35.25$ (Fig $5 \mathrm{~d}$ right), this latter value corresponding to open ocean conditions. The bottom salinity situation (Fig. 5b right) is contrasted with a single mode around 34.25-35.25 and no secondary peak for high bottom salinity values.

\section{$\underline{\text { Stratification }}$}

Anchovy spawning is related to mixing depth, with greater egg presence in shallow mixed layer conditions (Fig. 5e left). Eggs are generally found in very low number in waters with mixed layer depth greater than $50 \mathrm{~m}$. This is combined with a preference for

10 either weakly stratified (PED $<30 \mathrm{~J}$ ) or highly stratified waters (PED $>110 \mathrm{~J}$, Fig. 5f left). The combination of shallow mixed layer depth and high stratification corresponds to river plume waters with strong and shallow haline stratification. The high values of the GAM for unstratified waters corresponds to tidally mixed coastal waters. The situation for sardine is almost reversed, with egg abundance decreasing as stratification

15 increases (Fig $5 \mathrm{f}$ right) and eggs found throughout the range of mixing depths with higher presence probabilities for either deep or very shallow mixed layers (Fig. 5e right).

\section{$\underline{\text { Ranking of hydrographic predictors }}$}

Aside from the shape of the relationship between a given predictor and egg presence, it

20 is possible to rank the hydrographic predictors according to the percentage of deviance they can explain and the GCV scores of the GAM models (Table 1). For anchovy, the predictor that can best explain egg presence is bottom temperature, with the highest deviance (35\%) and lowest GCV score (0.508). Following predictors are surface temperature and mixed-layer depth and to a lesser extent surface salinity. Bottom salinity and potential energy deficit seem to have a more marginal link to egg presence, with percentage of deviance explained of less than $10 \%$. The situation is not as clear for sardine, with all hydrographic predictors having close values of both percentage of deviance explained and GCV scores. The generally lower values of deviance explained for sardine compared to anchovy suggest that hydrographic influence on sardine spawning areas is more limited than for anchovy. 


\section{Multiple predictor GAMs}

GAMs with increasing number of predictors (1 to 6) have been constructed. For each level, all possible arrangements of predictors were tested and only the best combination (i.e. with the lowest GCV score) was retained. The results of these models are presented in Table 2. For anchovy, the quality of the models increases up to 5 predictors, although little is gained beyond the 3-predictors model which includes bottom temperature, surface salinity and surface temperature. For sardine, there is a regular increase in model quality (both in terms of GCV and deviance) as the number of predictors increases, and the best model includes all hydrographic predictors. The overall percentage of deviance explained is always lower than for anchovy, a result consistent with previous observations on single predictor models.

\section{Model simulations}

Using hydrodynamical simulations for year 1999, we have extracted the 6 hydrographic descriptors and used them for the prediction of egg presence probability. For anchovy, the model with 3 predictors was retained, whereas for sardine all 6 predictors were used, for the reasons given above. Predictions were restricted for areas less of $1000 \mathrm{~m}$ depth. When modelled hydrographic predictors were outside the range of observed values, no prediction for egg presence probability was estimated.

The modelled potential habitats for sardine and anchovy during spring 1999 are presented in Figure 6 for four dates: 12 March, 6 April, 30 April and 24 May.

At the end of winter (12/03) the modelled potential spawning habitat of anchovy is almost absent from the Bay of Biscay continental shelf, apart from a small coastal region north of Spain and west of $3^{\circ} \mathrm{W}$. In early spring potential spawning habitat extends further east and along the French coast from the south of the Bay of Biscay up to the Gironde estuary. The potential habitat extends further offshore towards the north. Along the coast to the north of the Gironde estuary, the hydrographic conditions are not within the range of the GAMs, so there is no prediction of the potential spawning habitat for this region. At the end of April, the southern part of the Bay seems less favourable for spawning whilst to the north of the Gironde the potential habitat extends further towards the middle of the shelf. It is also noticeable that potentially suitable spawning habitats are seen along the southern coast of Brittany. In late May the hydrographic conditions appear favourable over a wide area south of $46^{\circ} \mathrm{N}$ and more 
restricted towards the coast in the north. There are small potentially favourable locations along the shelf break from 45 to $46 \mathrm{~N}$. The coastal band along the Northern coast of Spain also seems potentially suitable for spawning.

The modelled potential spawning habitat of sardine generally covers larger areas and is more patchy than that of anchovy. In late winter, most of the coast along northern Spain appears favourable for spawning, as well as the southern part of the Bay of Biscay up to $45 \mathrm{~N}$, excluding a narrow coastal strip. Hydrographic conditions also appear favourable in patchy regions over the central shelf. By early spring the potential spawning habitat has extended over a broader area but preserve a similar geographical structure. At the

10 end of April, most of the continental shelf is suitable for sardine spawning. By late May, potential spawning habitat has restricted towards shallower waters, but also along the shelf break. 


\section{DISCUSSION}

The objective of the present work was to define the hydrographic conditions which are potentially suitable for spawning of anchovy and sardine in the Bay of Biscay. As stated in the definition of "potential spawning habitat", this would have required data collection over a wide range of environmental conditions, including areas and seasons when spawning does not/never occur. Since the field cruises are primarily designed to monitor anchovy and sardine populations, they are centred on the area and timing of spawning of the two species and therefore include only a fraction of the non-spawning sites and are limited in the range of hydrographic situations encountered. Extension of the spatial and seasonal coverage of the cruises would improve the general methodology, although this is often hardly achievable because of field sampling cost. Alternatively, inclusion of results from other cruises which are carried around the Iberian Peninsula, in the Celtic Sea, Irish Sea and Channel would certainly improve the results obtained and provide a more robust description of European anchovy and sardine

15 potential spawning habitats. The current description of potential habitat is limited to observations realised in the subsurface layer and could be improved if the vertical distribution of eggs was taken into consideration. This could be achieved by using vertical egg distribution models such as those of Sundby (1983) or Westgard (1989) which have been adapted to the Bay of Biscay respectively by Boyra et al. (2003) and

20 Petitgas et al. (2004). Previous studies (Coombs et al., 1985, Olivar et al., 2001, Boyra et al., 2003, Coombs et al., 2003) suggest that the vertical distribution of anchovy and sardine eggs is variable but in most cases a fraction of the eggs is always present in the first 5 meters (one notable exception is the absence of sardine eggs at the surface in one haul in the western Channel in Coombs et al., 1985). It therefore appears to be a reasonable assumption that if eggs are present in the water column they will be found at $3 \mathrm{~m}$ depth where the CUFES operates, and the presence/absence index used in the present study can be considered as a good proxy for presence or absence of eggs in the water column.

Additional hydrographic or environmental variables may also be considered, although it is practical to constrain the list of parameters to a small number of variables that are regularly measured during field cruises and which provide a thorough description of the water column structure. The simulations of potential spawning habitat relies heavily on the capability of the hydrodynamical model to mimic realistically hydrographic 
conditions. It is expected that undergoing developments of the existing model will provide improved capabilities for habitat hind-, now- or fore-casting.

Another variable which can potentially influence the spatial extent of spawning is the biomass of adult fish spawning. During the spring cruises, sardine and anchovy adult biomass are estimated by means of acoustics at the time when fish eggs are sampled with the CUFES, and this allows for direct comparison between biomass and egg distribution at the time of sampling. The relationship between observed biomass and mean probability of egg presence for anchovy is almost null $\left(r^{2}=0.02, n=5\right)$. For sardine there is a positive relationship $\left(r^{2}=0.6, n=4\right)$ but it results from one year of observation

10 only, in 2001, when the estimated biomass was low and the mean probability of egg presence was also low. As a result, it is not possible to conclude that year-to-year variations in realised spawning habitat is directly linked to adult fish biomass, at least for the period studied in the present work (although it may be true over longer periods of time as suggested in Bellier et al., submitted).

15 The present analysis shows that potential spawning habitat of sardine and anchovy in the Bay of Biscay can be at least partially modelled using hydrographic predictors. Surprisingly, bottom temperature appears to be the best predictor for anchovy potential spawning habitat, followed by surface temperature and mixed-layer depth, whilst surface and bottom salinity appear to play a lesser role (Tables 1 and 2). To our knowledge the importance of bottom temperature has not been reported before, probably because it has rarely been measured in similar studies (many studies use satellite imagery or subsurface hydrographic measures and are therefore restricted to surface temperature). It is likely that anchovy are not directly dependent on temperature close to the bottom, but since temperature displays little gradient below the thermocline, bottom temperature appears as a good proxy for the conditions between the bottom and the thermocline. The lower limit of bottom temperature is about $12^{\circ} \mathrm{C}$, a value that corresponds to a cold bottom body of water found in the Bay of Biscay and known as the "cold pool" (Vincent and Kurc, 1969, Puillat et al., 2004). This structure is known to be present from southern Brittany, down to the latitude of the Gironde estuary, centred over the 100-m depth zone. Its location corresponds to the zone of weak tidal stirring, between areas of stronger vertical mixing along the coast and along shelf break (Le Fèvre, 1986). It is difficult to specify a spawning thermal range from the results in Figure 5, but the optimal surface temperature for spawning appears to be around $17^{\circ} \mathrm{C}$, a value consistent with previous findings obtained with independent data in the same 
region (Arbault and Lacroix, 1977, Motos et al., 1996). The moderate role of salinity in the Bay of Biscay is consistent with the findings of Reid (1966) at the scale of the global ocean. Aside from temperature effects, high egg abundance seems to prevail in either coastal well mixed areas (i.e. shallow mixed-layer and low stratification energy) or highly stratified river plumes (i.e. shallow mixed-layer depth, high stratification and low surface salinity, Fig. 5).

The possible influence of hydrographic factors on the spawning habitat of sardine seems less clear than for anchovy (Tables 1 and 2). This result is consistent with sardine behaviour which is known to swim large distance (Parrish et al., 1981, Doston and

10 Griffiths, 1996), to have a more fragmented spatial distribution (Barange and Hampton, 1997, Curtis, 2004) and to be generally more environmentally flexible than anchovy (Bakun and Broad, 2003). All hydrographic factors appear to have a similar degree of influence on the spawning distribution of sardine. Sardine appears to have a greater tolerance than anchovy for low bottom temperature (Fig. 5) although it also appears to avoid cold pool waters. The range of optimal surface temperature is also shifted towards lower values $\left(12-15^{\circ} \mathrm{C}\right)$ which is consistent with the results of Arbault and Lacroix (1977). Sardine eggs can be found in coastal waters (i.e. shallow mixing depth and low stratification energy), but contrary to anchovy they are also found in areas of deep mixing and low stratification energy which correspond to thermal rather than haline stratification in early spring. Sardines spawn over much of the area covered by the survey, and it is likely that the environmental conditions are not contrasted enough to exert a clear control on spawning within the region. Such control may be observed at larger scale, over the spatial and seasonal range of sardine spawning, as suggested by Stratoudakis et al. (2004).

25 The spatial distribution patterns generated from hydrodynamical simulations (Fig. 6) provide a first attempt to predict spawning habitats from environmental information only. The generated patterns are for potential spawning habitat rather than realised spawning habitat, so that it is not suggested that anchovy and sardine have actually spawned in all the habitat, but rather that the modelled habitats were available for 30 spawning.

The modelled succession of spatial patterns for anchovy potential spawning habitat in 1999 is in agreement with field observations, as describe in Motos et al. (1996), with early spawning taking place along the coast in the southern part of the Bay, followed by 
increasing spawning off the Gironde estuary and a gradual displacement towards northern coastal latitudes to the South of Brittany. The late spawning at the shelf break north of $45^{\circ} \mathrm{N}$ is not well reproduced, although there are areas with high probability of egg presence but with very restricted spatial extension. The modelled succession of 5 spatial patterns for sardine is also consistent with existing field observations, with potential spawning habitat showing a more fragmented distribution and covering a larger area than for anchovy and progressively extending northward as the season progresses. As for anchovy, the shelf break spawning sites are reproduced by the model, but with very restricted spatial extent, at the edge of the model geographical boundaries. 


\section{CONCLUSION}

Overall, the simulations suggest that a large fraction of previously observed seasonal patterns in spatial distribution of spawning can be explained by seasonal changes in hydrographic conditions. Such conditions can be seen as providing the 'hydrographic

5 envelope' of the spawning species, a notion which can be related to the more general 'bioclimate envelope' or 'climate space' (see Pearson and Dawson, 2003 and references therein). This provides good hope that realistic climate driven simulation can lead to realistic assessment of hydrographic impact on anchovy and to a lesser extent sardine potential spawning habitat spatial and temporal extent. However, one must not forget

10 that predicting potential spawning habitat is not predicting realised spawning and even less predicting spawning success which depends upon adult population structure, biological conditions in the ocean (e.g. predators and preys) as well as environmental hydrodynamical conditions after spawning. The proposed methodology provides a mean for assessing changes in potential spawning habitat in the context of predicted climate

15 variability and change. Whether or not these habitats will be used and will contribute to population growth remains an open question. 


\section{REFERENCES}

Agostini, V. N. and Bakun, A. (2002) 'Ocean triads' in the Mediterranean Sea: physical mechanisms potentially structuring reproductive habitat suitability (with example application to European anchovy, Engraulis encrasicolus). Fish. Oceanogr. 11: 129-142.

Ahlstrom, E. H. (1965) A review of the effects of the environment of the Pacific sardine. ICNAF Special Pub. 6: 53-76.

Allain, G., Petitgas, P. and Lazure, P. (2001) The influence of meso-scale ocean processes on anchovy (Engraulis encrasicolus) recruitment in the Bay of Biscay estimated with a three-dimensional hydrodynamic model. Fish. Oceanogr. 10: 151-163.

Anonymous (1985) FAO Species catalogue. Clupeoids fishes of the world. FAO Fisheries Synopsis 7: 579pp.

Arbault, S. and Boutin, N. (1967) Oeufs et larves de poissons téléostéens dans le golfe de Gascogne en 1964. Cons. Int. Explor. Mer. Comité Plancton, nº ${ }^{\circ}: 11$ :

Arbault, S. and Lacroix, N. (1971) Aires de ponte de la sardine, du sprat et de l'anchois dans le golfe de Gascogne et sur le plateau Celtique. Résultats de 6 années d'études. Rev. Trav. Inst. Pêches Marit. 35: 35-56.

Arbault, S. and Lacroix, N. (1977) Oeufs et larves de clupeides et engraulides dans le golfe de Gascogne (1969-1973). Distribution des frayères. Relations entre les facteurs du milieu et la reproduction. Rev. Trav. Inst. Pêches Marit. 41: 227-254.

Bakun, A. (1996) Patterns in the Ocean. Ocean processes and marine population dynamics. La Jolla, California Sea Grant College System, 323pp.

Bakun, A. and Broad, K. (2003) Environmental 'loopholes' and fish population dynamics: comparative pattern recognition with focus on El Niño effects in the Pacific. Fish. Oceanogr. 12: 458-473.

Barange, M. and Hampton, I. (1997) Spatial structure of co-occuring anchovy and sardine populations from acoustic data: implications for survey design. Fish. Oceanogr. 6: 94-108. 
Bellier, E., Planque, B. and Petitgas, P. (submitted) Historical fluctuations in spawning location of anchovy (Engraulis encrasicolus) and sardine (Sardina pilchardus) in the Bay of Biscay during 1967-1973 and 2000-2004. Fish. Oceanogr.

Boyra, G., Rueda, L., Coombs, S. H., Sundby, S., Adlandsvisk, B., Santos, M. and Uriarte, A. (2003) Modelling the vertical distribution of eggs of anchovy (Engraulis encrasicolus) and sardine (Sardina pilchardus). Fish. Oceanogr. 12: 381-395.

Checkley, D. M. J., Dotson, R. C. and Griffiths, D. A. (2000) Continuous, underwaysampling of eggs of Pacific sardine (Sardinops sagax) and northern anchovy (Engraulis mordax) in spring 1996 and 1997 off southern and central California. Deep Sea Res. 247: 1139-1155.

Checkley, D. M. J., Ortner, P. B., Cummings, S. R. and Settle, L. R. (1997) A continuous underway fish eggs sampler. Fish. Oceanogr. 6: 58-73.

Coombs, S. H., Fosh, C. A. and Keen, M. A. (1985) The buoyancy and vertical distribution of eggs of sprat (Sprattus sprattus) and pilchard (Sardina pilchardus). J. Mar. Biol. Ass. UK 65: 461-474.

Coombs, S. H., Giovanardi, O., Halliday, N. C., Franceschini, G., Conway, D. V. P., Manzueto, L., Barrett, C. D. and McFadzen, I. R. B. (2003) Wind mixing, food availability and mortality of anchovy larvae Engraulis encrasicolus in the northern Adriatic Sea. Mar. Ecol. Prog. Ser. 248: 221-235.

Cressie, N. A. C. (1993) Statistics for spatial data. Revised Edition. New York: Wiley Inter-science, 900pp.

Curtis, K. A. (2004) Fine scale spatial pattern of pacific sardine (Sardinops sagax) and northern anchovy (Engraulis mordax) eggs. Fish. Oceanogr. 13: 239-254.

25 Daskalov, G. M., Boyer, D. C. and Roux, J. P. (2003) Relating sardine Sardinops sagax abundance to environmental indices in northern Benguela. Prog. Oceanogr. 59: 257-274.

Doston, R. C. and Griffiths, D. A. (1996) A high-speed mid-water rope trawl for collecting coastal pelagic fishes. CalCOFI Rep. 37: 134-139. 
Ettahiri, O., Berraho, A., Vidy, G., Ramdani, M. and Do chi, T. (2003) Observation on the spawning of Sardina and Sardinella off the south Moroccan Atlantic coast (21-26º N) Fish. Res. 60: 207-222.

Fage, L. (1911) Recherches sur la biologie de l'anchois (Engraulis encrassicholus Linné) - races - âge - migrations. Ann. Inst. Océanogr. 2(4): 45pp.

Fretwell, S. (1972) Populations in a seasonal environment. New Jersey: Princeton University Press, 217pp.

Furnestin, J. (1945) Contribution à l'étude biologique de la sardine atlantique (Sardina pilchardus WALBAUM). Rev. Trav. Off. Pêches Marit. 13: 221-386.

10 Furnestin, J. and Furnestin, M. L. (1959) La reproduction de la sardine et de l'anchois des côtes Atlantiques du Maroc (saisons et aires de pontes). Rev. Trav. Inst. Pêches Marit. 23: 79-104.

Hammann, M. G., Nevarez-Martinez, M. O. and Green-Ruiz, Y. (1998) Sapwning habitat of the Pacific sardine (Sardinops sagax) in the Gulf of California: egg and larval distribution 1956-1957 and 1971-1991. CalCOFI Rep. 39: 169-179.

Hastie, T. J. and Tibshirani, R. J. (1990) Generalized additive models. Chapman and Hall, 335pp.

Lazure, P. and Jégou, A.-M. (1998) 3D modelling of seasonal evolution of Loire and Gironde plumes on Biscay bay continental shelf. Oceanol. Acta 21: 165-177.

20 Le Fèvre, J. (1986) Aspects of the biology of frontal systems. Adv. Mar. Biol. 23: 163299.

Lloret, J., Palomera, I., Salat, J. and Sole, I. (2004) Impact of freshwater input and wind on landings of anchovy (Engraulis encrasicolus) and sardine (Sardina pilchardus) in shelf waters surrounding the Ebre (Ebro) River delta (northwestern Mediterranean). Fish. Oceanogr. 13: 102-110.

Lluch-Belda, D., Lluch-Cota, D. B., Hernandez-Vasquez, S., Salina-Zavala, C. A. and Schwartzlose, R. A. (1991) Sardine and anchovy spawning as related to temperature and upwelling in the California Current system. CalCOFI Rep. 32: 105-111.

30 Lynn, R. J. (2003) Variability in the spawning habitat of Pacific sardine (Sardinops sagax) off southern and central California. Fish. Oceanogr. 12: 541-553. 
MacCall, A. D. (1990) Dynamic geography of marine fish populations. Washington, University of Washington Press, 153pp.

Matheron, G. (1962) Traité de Géostatistique appliquée. Paris, Bureau de recherches géologiques et minières, $171 \mathrm{pp}$.

5 Motos, L., Uriarte, A. and Valencia, V. (1996) The spawning environment of the Bay of Biscay anchovy (Engraulis encrasicolus L.). Sci. Mar. 60 (Supl. 2): 117-140.

Olivar, M. P., Salat, J. and Palomera, I. (2001) Comparative study of spatial distribution patterns of the early stages of anchovy and pilchard in the NW Mediterranean Sea. Mar. Ecol. Prog. Ser. 217: 111-120.

10 Parrish, R. H., Nelson, C. S. and Bakun, A. (1981) Transport mechanisms and reproductive success of fishes in the California Current. Biol. Oceanogr. 1: 175203.

Parrish, R. H., Serra, R. and Grant, W. S. (1989) The monotypic sardines, Sardina and Sardinops: their taxonomy, distribution, stock structure and zoogeography. Can. J. Fish. Aquat. Sci. 46: 2019-2036.

Pearson, R. G. and Dawson, T. P. (2003) Predicting the impacts of climate change on the distribution of species: are bioclimate envelope models useful? Global Ecol. Biogeogr. 12: 361-372.

Petitgas, P., Magri, S. and Lazure, P. (2004) A one-dimensional model for the vertical distribution of fish eggs: sensitivity analysis and validation. ICES CM 2004/P:34, 37pp.

Planque, B., Lazure, P. and Jegou, A. M. (2004) Detecting hydrological landscapes over the Bay of Biscay continental shelf in spring. Clim. Res. 28: 41-52.

Puillat, I., Lazure, P., Jégou, A. M., Lampert, L. and Miller, P. (2004) Hydrographical variability on the French continental shelf in the Bay of Biscay during the 1990's. Cont. Shelf Res. 24: 1143-1164.

$\mathrm{R}$ Development Core Team (2004) A language and environment for statistical computing. R Foundation for Statistical Computing. Vienna, Austria.: ISBN 3900051-00-3, URL http://www.R-project.org.

30 Reid, J. L. (1966) Oceanic environment of the genus Engraulis around the world. CalCOFI Rep. 11: 29-33. 
Sola, A., Motos, L., Franco, C. and Lago de Lanzos, A. (1990) Seasonal occurrence of pelagic fish eggs and larvae in the Cantabrian Sea (VIIIc) and Galicia (IXa) from 1987 to 1989. ICES CM 1990/H:25: 14pp.

Stenevik, E. K., Sundby, S. and Cloete, R. (2001) Influence of buoyancy and vertical distribution of sardine Sardinops sagax eggs and larvae on their transport in the northern Benguela ecosystem. S. Afr. J. mar. Sci. 23: 85-97.

Stratoudakis, Y., Coombs, S. H., Halliday, N. C., Conway, D. V. P., Smyth, T. J., Costas, G., Franco, C., de Lanzos, A. L., Bernal, M., Silva, A., Santos, M. B., Alvarez, P. and Santos, M. (2004) Sardine (Sardina pilchardus) spawning season in the North East Atlantic and relationships with sea surface temperature. ICES CM 2004/Q:19: 19pp.

Sundby, S. (1983) A one-dimensional model for the vertical distribution of pelagic fish eggs in the mixed layer. Deep Sea Res. 1 30: 645-661.

Tibby, R. B. (1937) The relation between surface water temperature and the distribution of spawn of the California sardine (Sardinops caerulea). Cal. Fish. Game 23: 132-137.

Uriarte, A., Prouzet, P. and Villamor, B. (1996) Bay of Biscay and Ibero Atlantic anchovy populations and their fisheries. Sci. Mar. 60 (Suppl. 2): 237-255.

van der Lingen, C. D. and Castro, L. (2004) SPACC workshop and meeting on spawning habitat and assessment of small pelagic fish, Conception, Chile, 12-16 January 2004. Globec International Newsletter 10: 28-31.

van der Lingen, C. D., Hutchings, L., Merkle, D., van der Westhuizen, J.-J. and Nelson, J. (2001) Comparative spawning habitats of anchovy (Engraulis capensis) and sardine (Sardinops sagax) in the southern Benguela upwelling ecosystem. In Spatial processes and management of marine populations. University of Alaska Sea Grant College Program, Anchorage Alaska: 185-209.

Vincent, A. and Kurc, G. (1969) Hydrologie, variations saisonnières de la situation thermique du Golfe de Gascogne en 1967. Rev. Trav. Inst. Pêches Marit. 33: 7996.

30 Ward, T. and Staunton-Smith, J. (2002) Comparison of the spawning patterns and fisheries biology of the sardine, Sardinops sagax, in temperate South Australia and sub-tropical southern Queensland. Fish. Res. 56: 37-49. 
Westgard, T. (1989) Two models for the vertical distribution of pelagic fish eggs in the turbulent upper layer of the ocean. Rapp. P.-v. Réun. Cons. int. Explor. Mer 191: 195-200.

Wood, S. N. and Augustin, N. H. (2002) GAMs with integrated model selection using penalized regression splines and applications to environmental modelling. Ecol. Model. 157: 157-177. 
Table 1. Single predictor GAM fits for anchovy and sardine. For each predictor, the percentage of deviance and the Generalised Cross Validation score is given.

\begin{tabular}{|l|cc|cc|}
\hline & \multicolumn{2}{|c|}{ Anchovy } & \multicolumn{2}{c|}{ Sardine } \\
\hline Parameter & \% deviance & GCV score & \% deviance & GCV score \\
\hline BT (bottom temperature) & 35.3 & 0.508 & 10.0 & 0.516 \\
BS (bottom salinity) & 6.7 & 0.648 & 13.1 & 0.483 \\
ST (surface temperature) & 16.5 & 0.614 & 10.9 & 0.520 \\
SS (surface salinity) & 10.2 & 0.633 & 8.5 & 0.517 \\
MLD (mixed-layer depth) & 15.2 & 0.602 & 10.8 & 0.506 \\
PED (potential energy deficit) & 7.0 & 0.635 & 13.7 & 0.494 \\
\hline
\end{tabular}

Table 2. Multiple predictors GAM fits for anchovy and sardine. The models retained for spawning habitat prediction are highlighted in grey.

\begin{tabular}{|l|cc|}
\hline & \multicolumn{2}{|c|}{ Anchovy } \\
\hline Model & \% deviance & GCV score \\
\hline 1: BT & 35.3 & 0.508 \\
2: BT + SS & 39.2 & 0.484 \\
3: BT + SS + ST & 45.3 & 0.452 \\
4: BT + SS + ST + MLD & 46.6 & 0.443 \\
5: BT + SS + ST + MLD + BS & 47.0 & 0.441 \\
6: BT + SS + ST + MLD + BS + PED & 48.8 & 0.443 \\
\hline & \multicolumn{2}{|c|}{ Sardine } \\
\hline Model & \% deviance & GCV score \\
\hline 1: BS & 13.1 & 0.482 \\
2: BS + BT & 19.2 & 0.464 \\
3: BS + SS + PED & 30.5 & 0.419 \\
4: BS + SS + PED + ST & 33.6 & 0.407 \\
5: BS + SS + ST + BT + MLD & 38.4 & 0.392 \\
\hline 6: BS + SS + ST + BT + MLD + PED & 41.0 & 0.378 \\
\hline
\end{tabular}




\section{Figure legends:}

Fig 1. A schematic representation of the three spawning habitat components: potential, realised and successful. Potential habitat is primarily influenced by pre-spawning environmental conditions which affect adults, realised habitat is primarily dependent on population size and demographic structure, and successful habitat varies primarily as a function of post-spawning environmental conditions which will affect egg and larval survival.

Fig 2. Spatial location of hydrological stations (open circles) and CUFES sampling midpoints (dots) during the cruise PELGAS2004. The location of the Loire, Gironde and Adour river mouths are indicated as well as Brittany and "Les Landes" regions. Bathymetry for 20, 50, 100, 200, 500 and $1000 \mathrm{~m}$ isobaths is also indicated.

Fig 3. Spatial distribution of sardine (top) and anchovy (bottom) in 2000, 2001, 2002, 2003 and 2004. Grey scale is proportional to the probability of presence ( $>1$ egg per $\mathrm{m}^{3}$ ) of eggs.

Fig 4. Spatial distribution of (a) sea surface temperature averaged over the first $5 \mathrm{~m}$, (b) sea bottom temperature averaged over the last $5 \mathrm{~m}$, (c) sea surface salinity averaged over the first $5 \mathrm{~m}$, (d) sea bottom salinity averaged over the last $5 \mathrm{~m}$, (e) mixed-layer depth and (f) potential energy deficit in 2000, 2001, 2002, 2003 and 2004. When bottom depth exceeds $100 \mathrm{~m}$, hydrological parameters are calculated from the first $100 \mathrm{~m}$. Black dots indicate location of CTD stations.

Fig 5. Generalised Additive Models (GAMs) for sardine and anchovy against bottom temperature (a), bottom salinity (b), surface temperature (c), surface salinity (d), mixedlayer depth (e) and potential energy deficit (f). Black thick lines indicate the value of GAMs coefficient, dotted line are the confidence intervals at $p=0.05$, and the horizontal line indicates zero level.

Fig 6. Modelled potential spawning habitat of anchovy (top) and sardine (bottom) in 1999. Grey scale is proportional to egg presence probability. Probabilities are derived from modelled hydrological fields and GAMs in Fig. 5. 


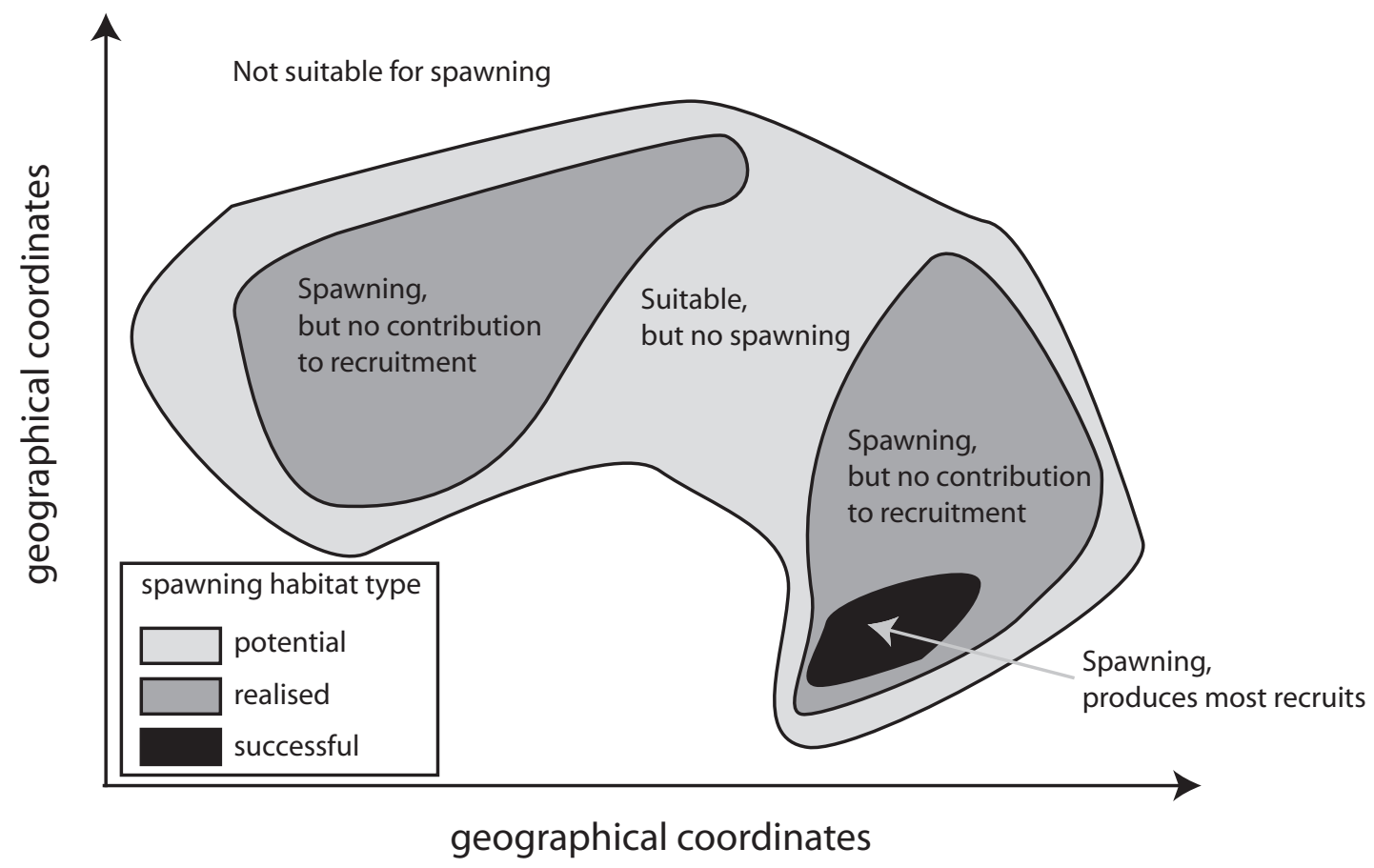

Figure 1 


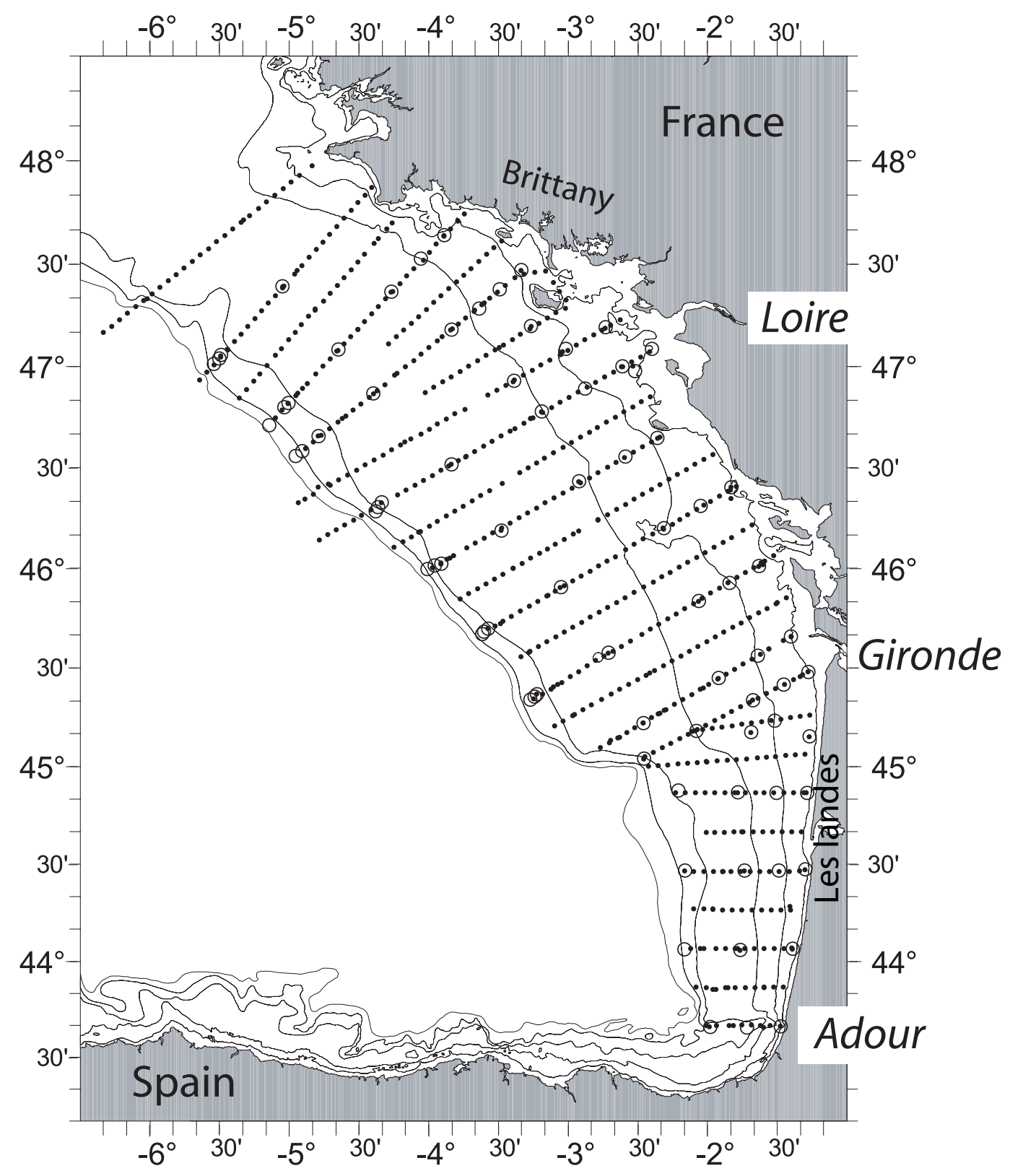

Figure 2 

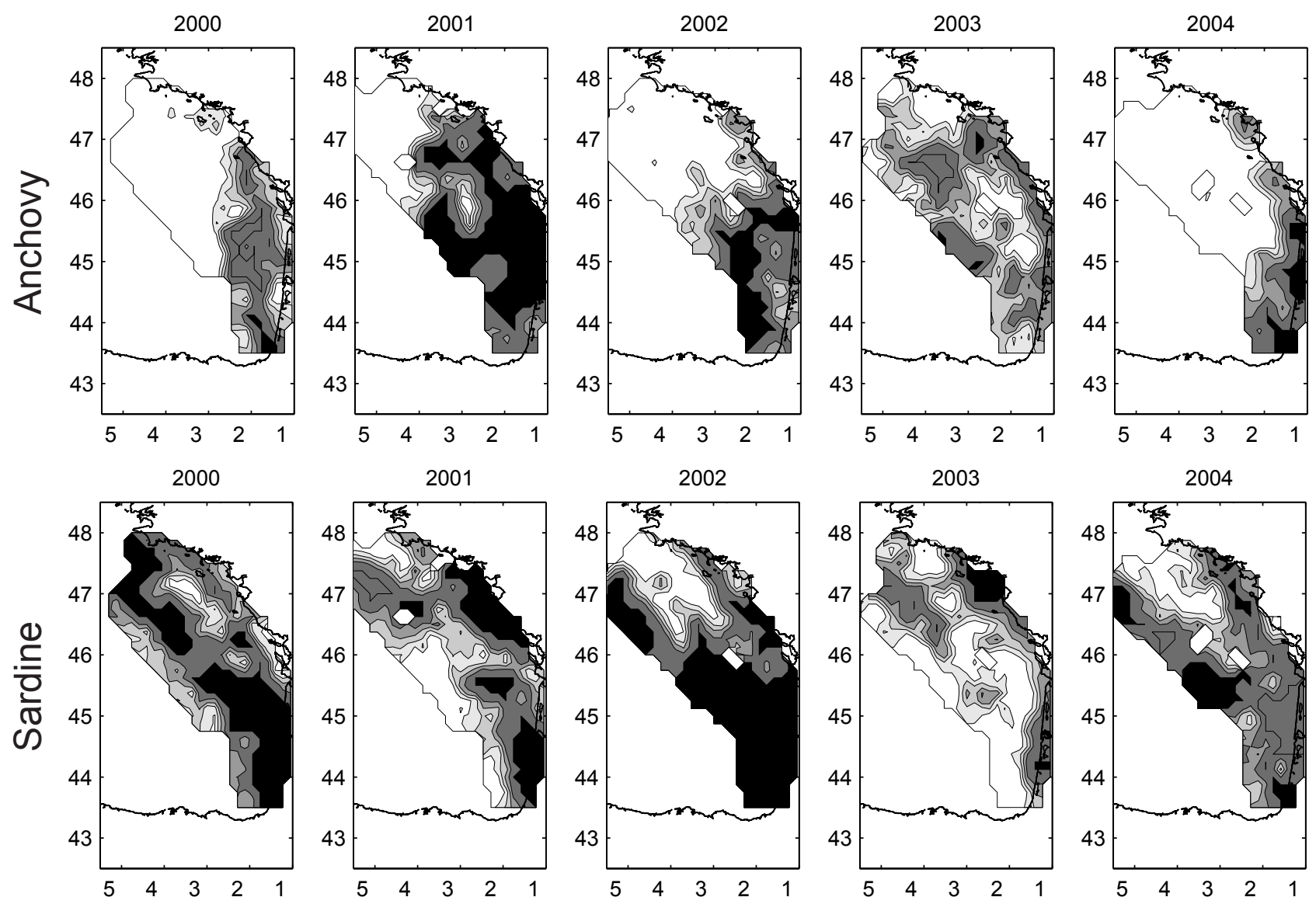

Probability of egg presence

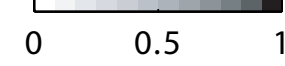



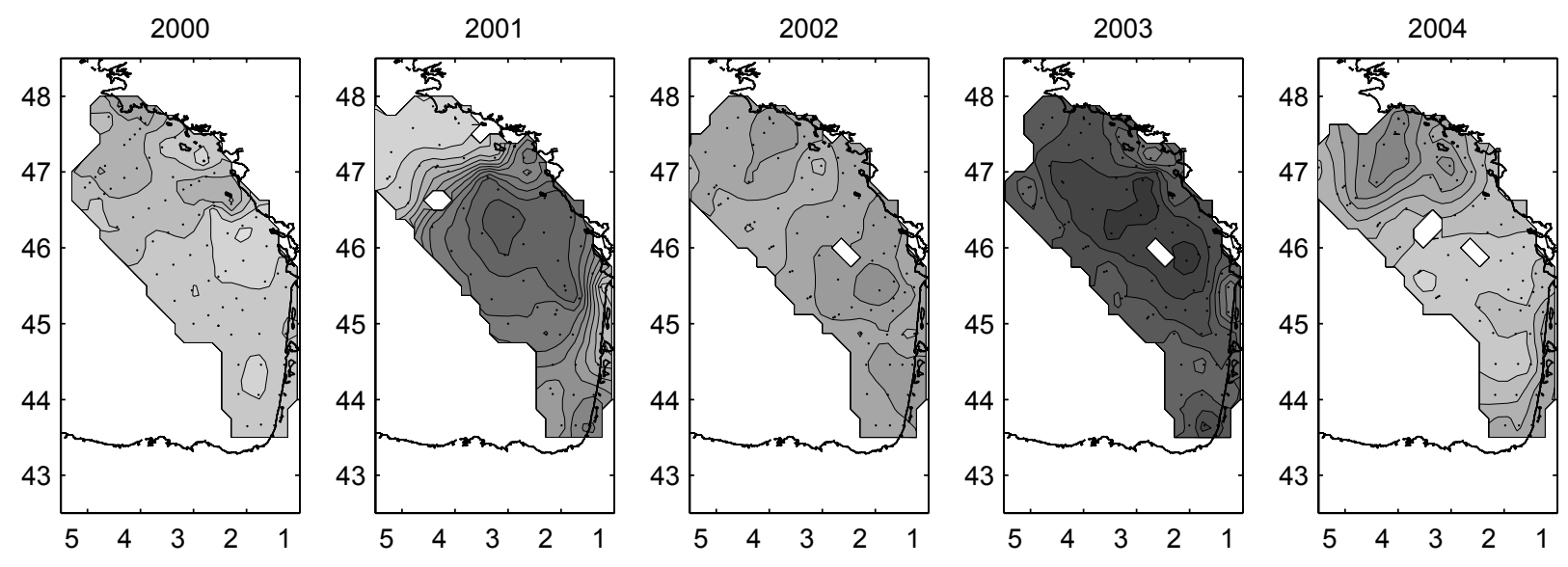

a
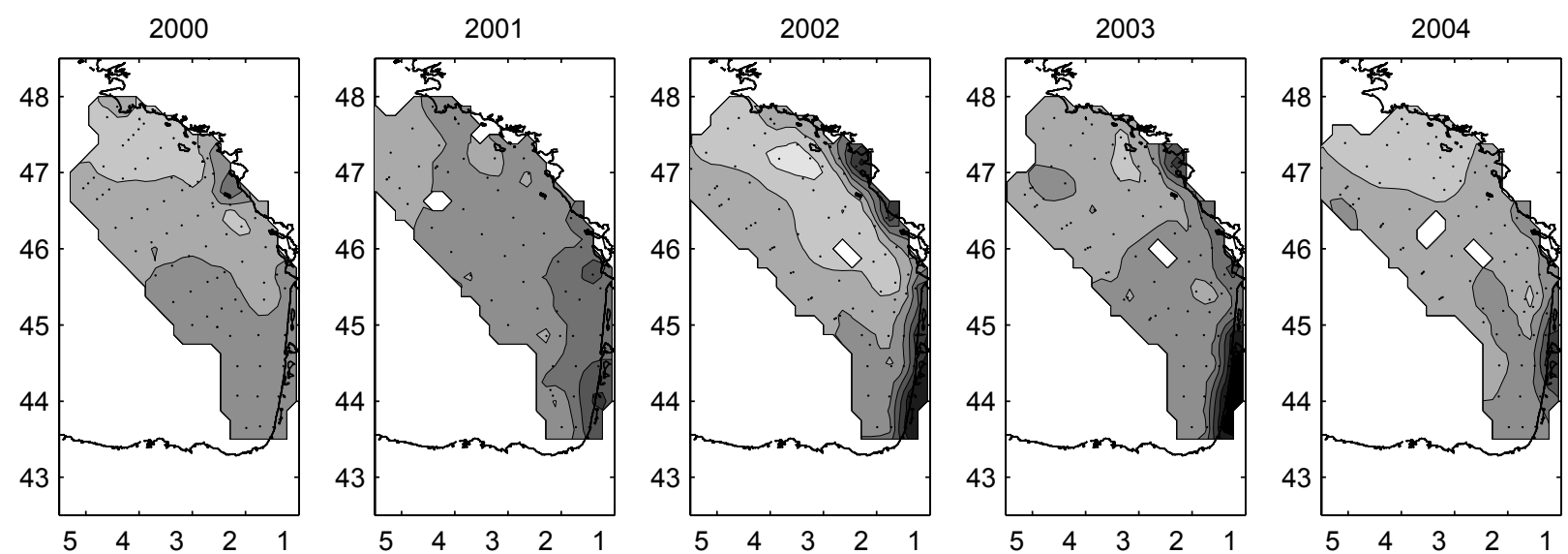

Surface

Temperature
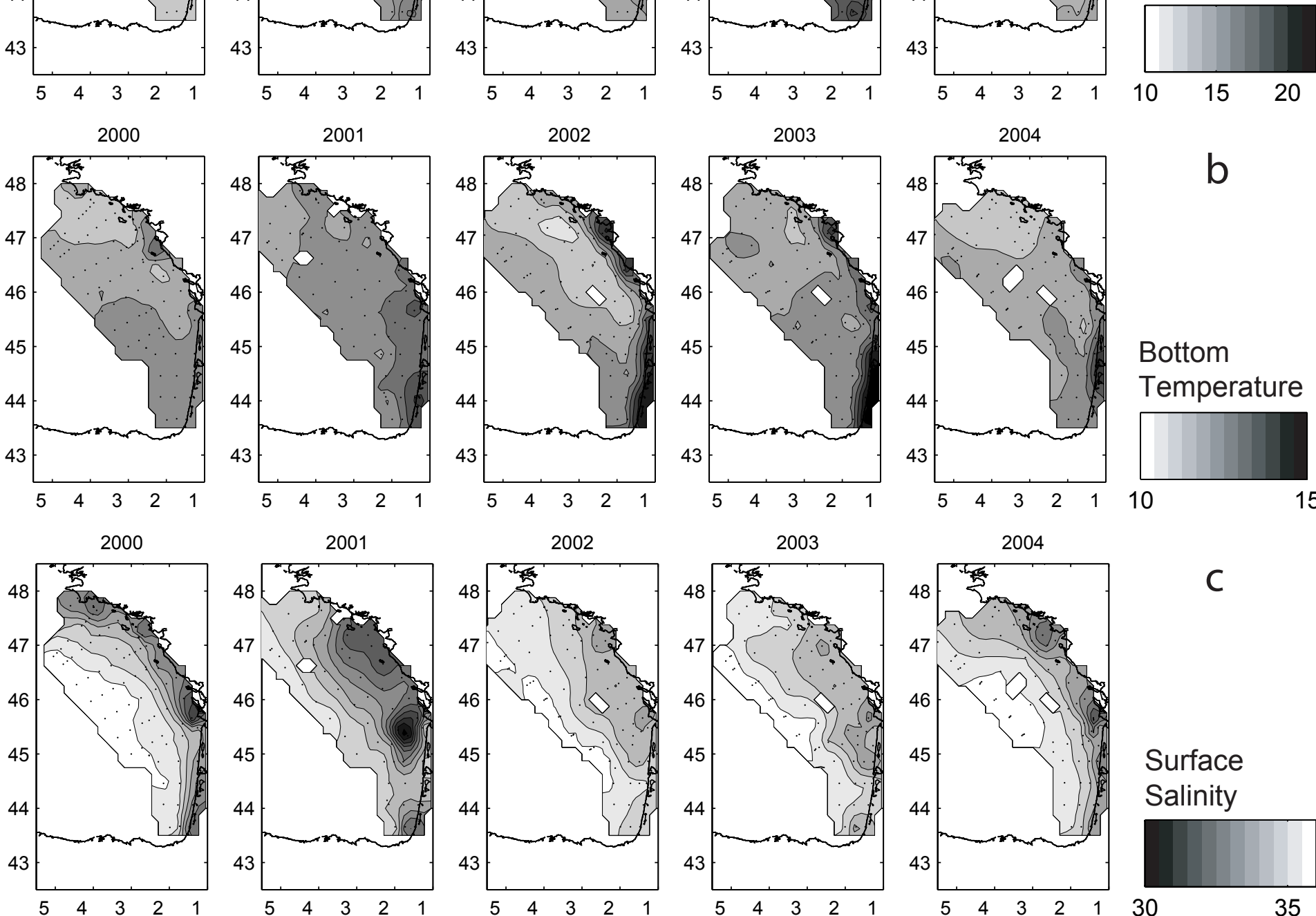

Bottom

Temperature
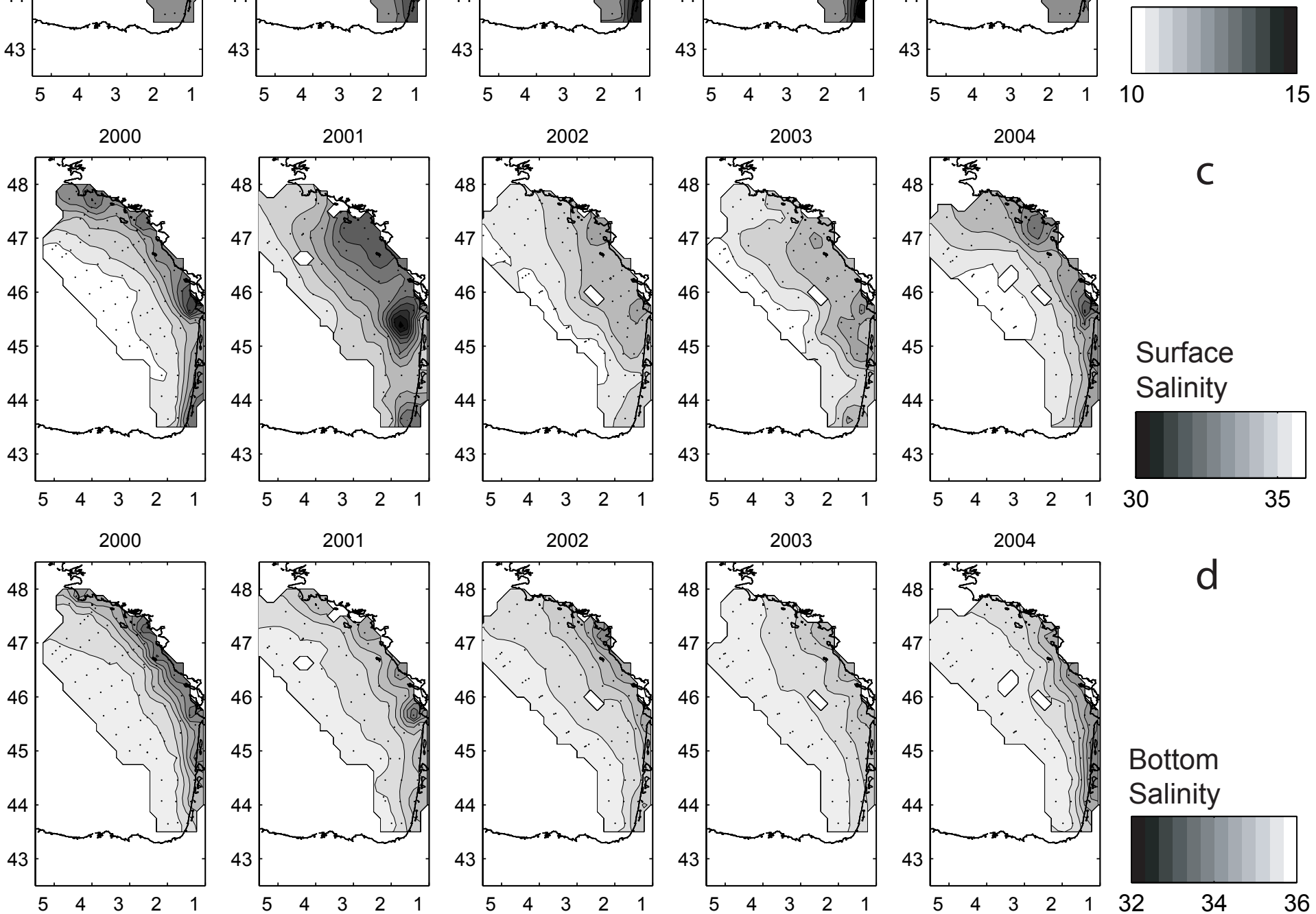

C

d

Bottom

Salinity

Figure 4 ... 

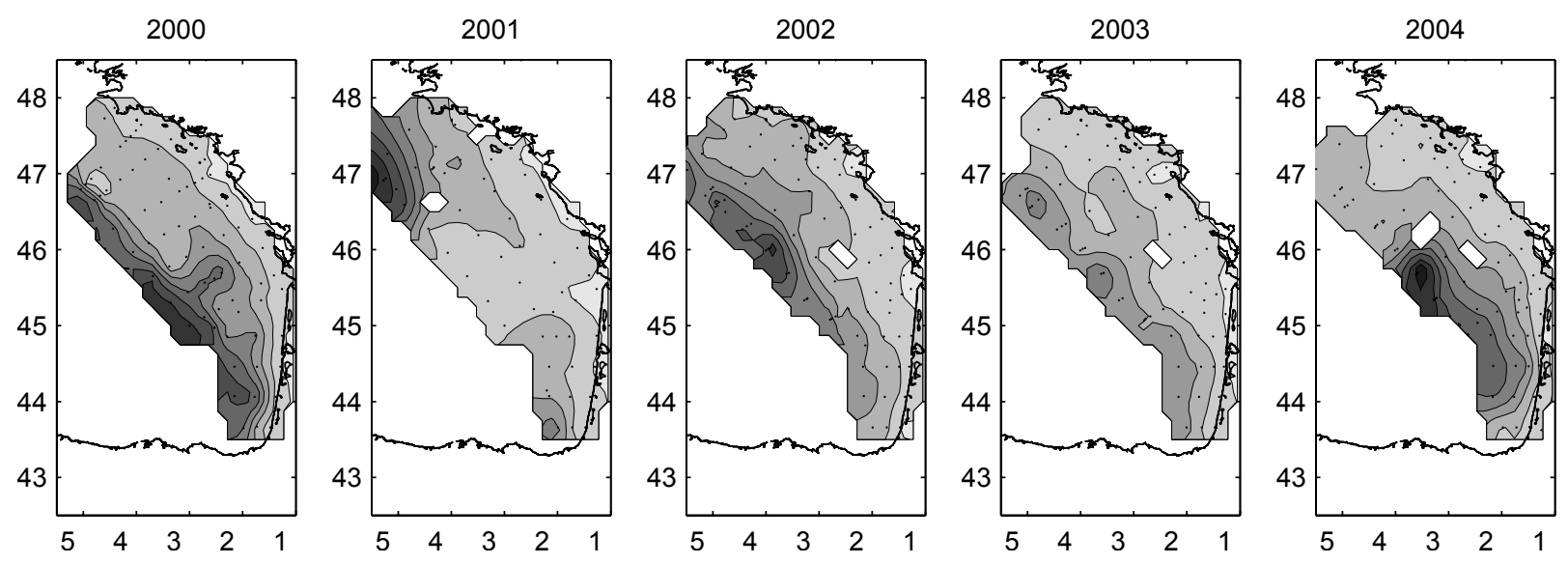

e
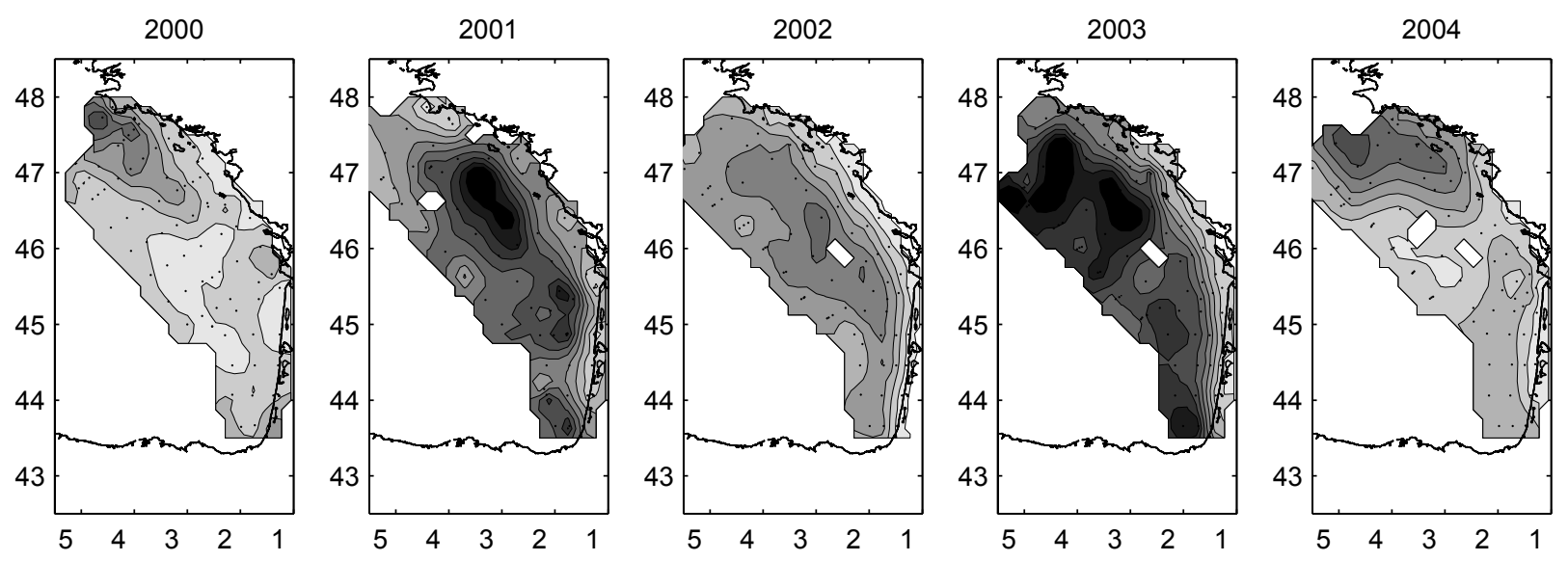

Mixed-layer

Depth

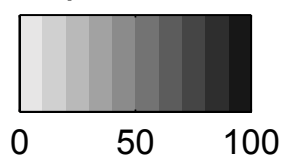

Potential

Energy

Deficit

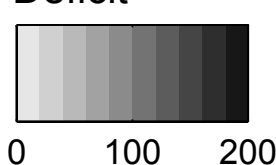

Figure 4 (continued) 


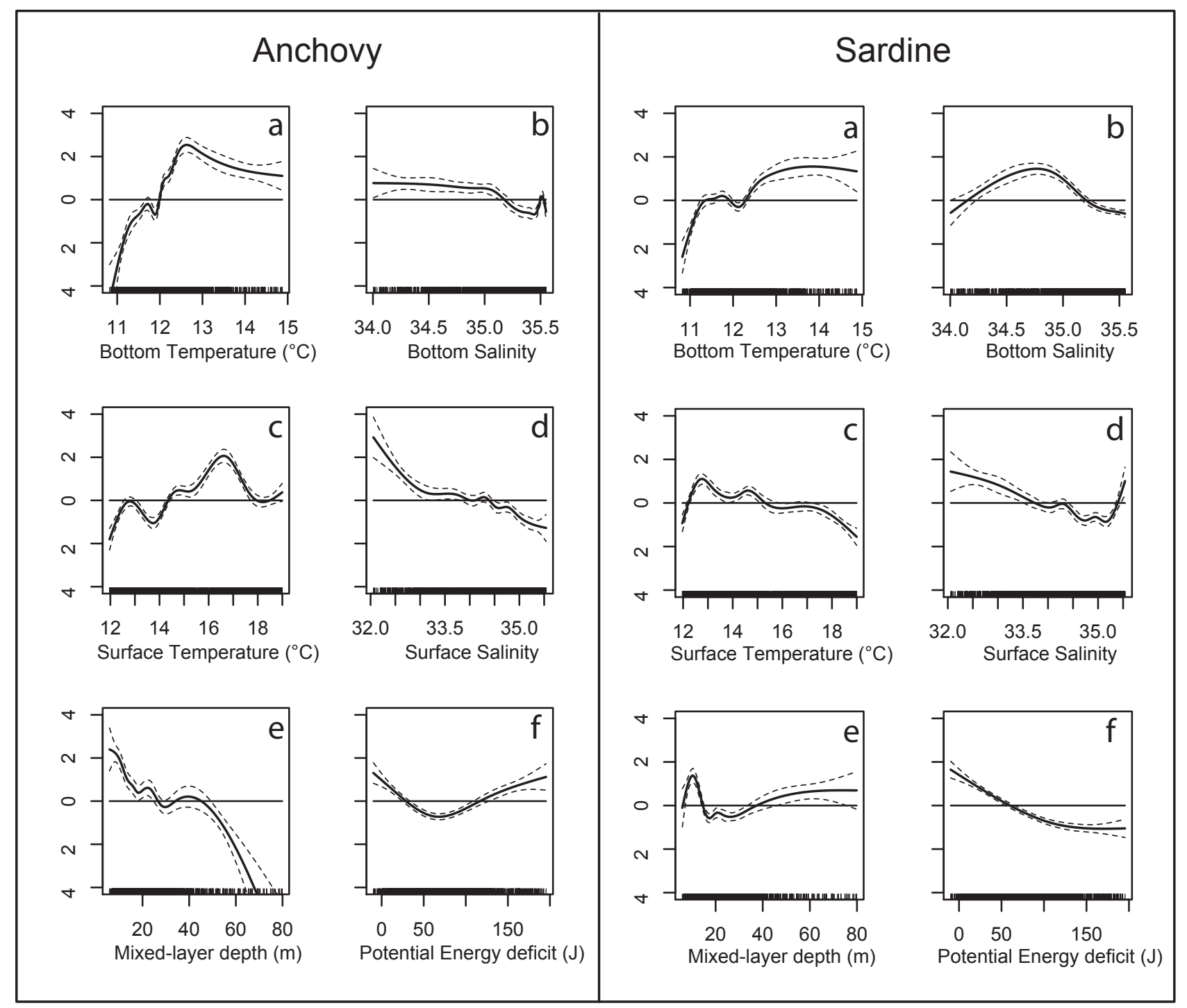

Figure 5 

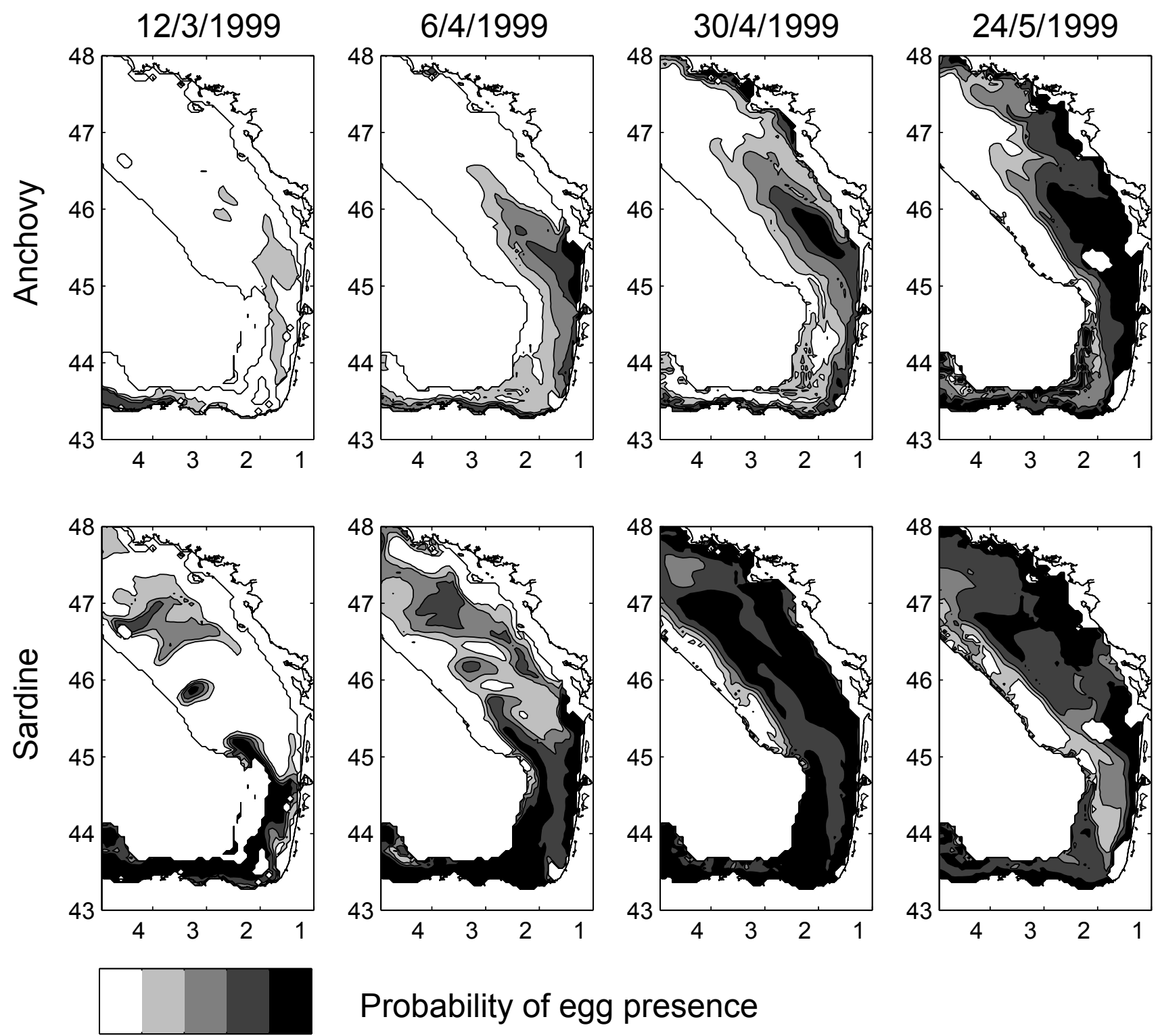

Probability of egg presence

$\begin{array}{llllll}0 & 0.2 & 0.4 & 0.6 & 0.8 & 1\end{array}$ 